MINERALOGIA, 41, No 1-2: 23-33 (2010)

DOI: $10.2478 / v 10002-010-0003-2$

www.Mineralogia.pl

MineRALOgICAL SOCIETY OF POLAND

Polskie TOWARZYSTWO MINERALOgICZNE

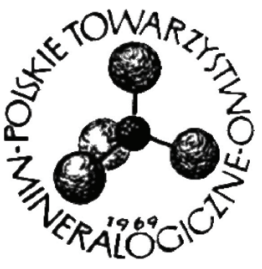

Original paper

\title{
Valences and site characteristics of iron in radioactive magmatic veins (Egypt): A Mössbauer and chemical study
}

\author{
Kamaledin M. HASSAN ${ }^{1}$ \\ ${ }^{1}$ Nuclear Materials Authority, P.O. Box 530, Maddi, Cairo, Egypt; \\ correspondence address: El-Estesmary Buildings, El-Remaih-Harm, P.O. Box 20, Giza 12572, Egypt \\ e-mail:egy100@yahoo.com
}

Received: March 3, 2010

Received in revised form: December 13, 2010

Accepted: December 14, 2010

Available online: February 9, 2011

Abstract. Radioactive veins in shear zones of the El-Seboah granite in Egypt with anomalous concentrations of $\mathrm{Nd}, \mathrm{Ce}, \mathrm{Zr}, \mathrm{Y}, \mathrm{Nb}, \mathrm{Sm}$, Th and $\mathrm{U}$ were studied by petrographic microscopy, x-ray diffraction, ${ }^{57} \mathrm{Fe}$ Mössbauer and wet chemical methods. The veins are composed essentially of quartz, aegirine-augite and minor K-feldspar \pm $\alpha$-iron oxide (hematite) $\pm \gamma$-iron oxide hydroxide (goethite). They likely represent late-stage felsic melt that was quenched and devitrified at high temperature to yield crystals and crystallites, and then subjected to low temperature alteration during which most of the $\mathrm{K}$ feldspar transformed to kaolinite and opal. Mössbauer parameters of the samples indicate that the existing Fe-bearing minerals are primary, with appreciable ordering in the Fe sites. The bulk-sample iron $(\Sigma \mathrm{Fe})$ contents are extremely high (12.3-22.4\%). The extent of oxidation of the $\mathrm{Fe}$ has been found to be $100 \%$ by Mössbauer spectroscopy and $95.36-99.69 \%$ by a chemical method. These conditions of $\mathrm{Fe}$ enrichment and strong oxidation suggest that the veins are extreme differentiates of granite magmas where high states of oxygen fugacity prevailed.

Key-words: Egypt, Mössbauer, peralkaline rocks, aegirine-augite, Fe-oxide phases, radioactive/rare metals

\section{Introduction}

Several radioactive magmatic veins fill shear zones, fractures and joints in the ElSeboah granite. The latter is a ring-like intrusion (Fig. 1) rising above the Nubian sand in the south Western Desert, Egypt, consisting mainly of quartz, feldspars and aegirine-augite. 
As is typical of the peralkaline-acidic rocks which are commonly associated with ring structures (List et al. 1989), it is characterized by an abundance of rare metals (Abdel Monem, El-Afandy 1997; Khalaf et al. 2000; NMA 2000). An account of the geochemical characteristics of the El-Seboah granite and its associated radioactive veins has been given by Hassan (2005).

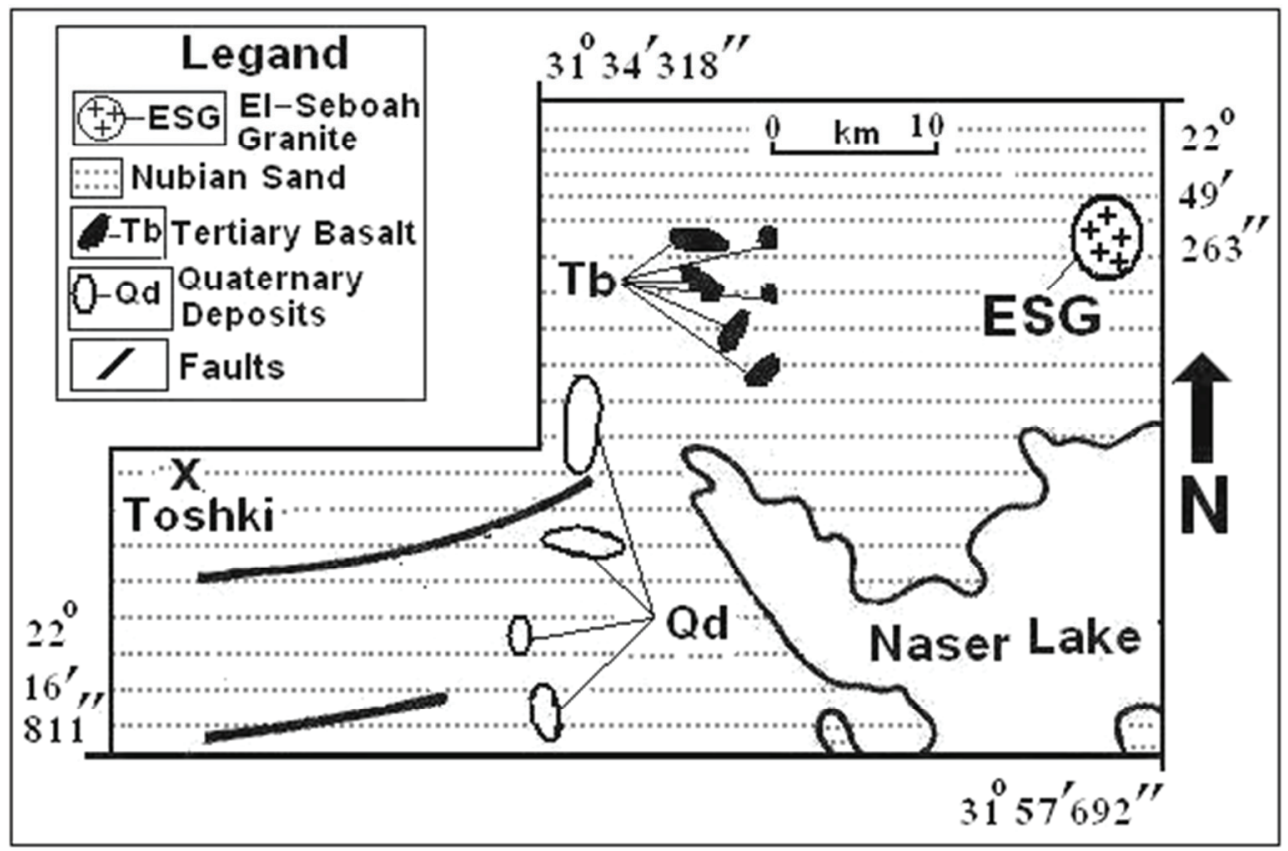

Fig. 1. Geological map of southwestern Desert, Egypt (modified from Hassan 2009b)

The radioactive veins of the El-Seboah granite are glassy (vitric) to fine grained masses that range in thickness from a few centimeters to $0.5 \mathrm{~m}$, and contain felsic phenocrysts and silica cavities. These veins, which probably represent late-stage melts, occur in brown, red and green colors. They are peralkaline and are enriched in total field gamma $(\gamma)$-ray radiation (up to eleven orders of magnitude more than the general radiation background). Enrichment is due mainly to thorium (Th) and, to a lesser extent, uranium (U), present in 240-387 and 40-51 parts per million (ppm), respectively. The Th/U anomalies are associated with other elemental anomalies, including up to $5287 \mathrm{ppm} \mathrm{Nd}$, 3957 ppm Ce, 3271 ppm Zr, 1578 ppm Y, 765 ppm Nb and 280 ppm Sm (Hassan 2005). All of these anomalies reflect trace mineral phases (i.e. zircon, thalenite) adsorbed on crystal surfaces (particularly $\mathrm{Fe}$ minerals) and also trapped in lattice imperfections.

The present study provides new data on the valences and site characteristics of $\mathrm{Fe}$ in the radioactive magmatic veins of the El-Seboah granite. These parameters provide insights into the genesis and evolution of the veins, a prospective environment for rare metal mineralization in the region. 


\section{Methods}

Nine samples (S1-S9) of the radioactive veins were examined in this study. Samples 1-2 and 4 are green, sample 3 is brown, and samples 5-9 are red. Thin sections were examined by optical microscope. X-ray diffraction analyses (6 samples) were carried out using a Philips diffractometer (type PW 1710) and the reflection peaks and relative peak intensities compared with ICDD files for mineral identification. The minerals identified were quantified by comparing the intensities of their diffraction peaks.

Chemical analyses of $\mathrm{Fe}$ in all samples were made using two standard techniques: $\mathrm{Fe}^{2+}$ was determined by the $\mathrm{KMnO}_{4}$ method (Scott, Furman 1952) and total iron $(\Sigma \mathrm{Fe})$ by the EDTA method (Welcher 1958). The $\mathrm{Fe}^{3+}$ content of each sample was determined by: $\Sigma \mathrm{Fe}-\mathrm{Fe}^{2+}=\mathrm{Fe}^{3+}$. Samples S1 and S2 were analyzed for Si by wet chemistry (Scott 1958), and for $\mathrm{Al}, \mathrm{Na}, \mathrm{K}, \mathrm{Ca}$ and $\mathrm{Mg}$ by atomic absorption.

Mössbauer measurements were conducted on the bulk fraction of all samples. Aliquots $(150 \mathrm{mg})$ were milled in an agate mortar to preserve the texture as closely as possible. Mössbauer spectra were obtained at room temperature using a spectrometer with $\mathrm{a}^{57} \mathrm{Co}(\mathrm{Rh})$ source (initial activity $=50 \mathrm{mCi}$ ). Velocity calibration was carried out using high purity metallic iron foil. The spectra were all obtained from the analyzer, where computer analysis was performed, and were fitted to Lorentzian line shapes in order to obtain accurate line parameters.

\section{Results and Discussions}

Microscopically, the veins are holocrystalline, subhedral, granular rocks consisting of quartz and aegirine, with some opaques (mainly iron oxides) and feldspars. Examples of photomicrographs are shown in Fig. 2. The feldspars are highly altered to silica (opal) and kaolinite. Quartz is present as coarse-grained, anhedral- to subhedral phenocrysts, fine to medium interstitial grains, and globular masses. Invariably, quartz grains show wavy extinction, have sutured edges and are not fractured. Cryptocrystalline quartz occurs as spherulities, and as fine aggregates forming pockets and microveinlets. This variety of quartz is either transparent or opaque, and is usually red, yellow, brown or black in color due mainly to iron impurities. Aegirine, ranging in size from tiny, acicular, medium to long prisms, commonly forms radiating aggregates and is occasionally enclosed poikilitically within large quartz and feldspar crystals. Aegirine crystals are slightly altered along cleavage planes.

The spherulitic texture suggests that the original material, which could be lateinjected melt or residual interstitial melt, was devitrified at high temperature to form a mixture of crystals and spherulites. The residual glass is more prone to alteration at lower temperature and this caused release of potassium to form kaolinite and opal (K-glass $\rightarrow \mathrm{K}$ feldspar $+\mathrm{H}_{2} \mathrm{O} \rightarrow 2 \mathrm{~K}^{+}$(lost) + kaolinite + opal).

$\mathrm{X}$-ray diffraction of the samples indicates the presence of aegirine-augite and quartz, with minor orthoclase \pm minor sanidine. Examples of XRD patterns are shown in Fig. 3. Traces of hematite and goethite also found were confirmed by Mössbauer analysis. There is little or no indication of a glassy contribution in the patterns shown. Some diffuse scattering in a broad diffuse peak around $12-20^{\circ}$ ( 2 Theta) may, at least, hint at crystalline phases included in a glassy matrix. 

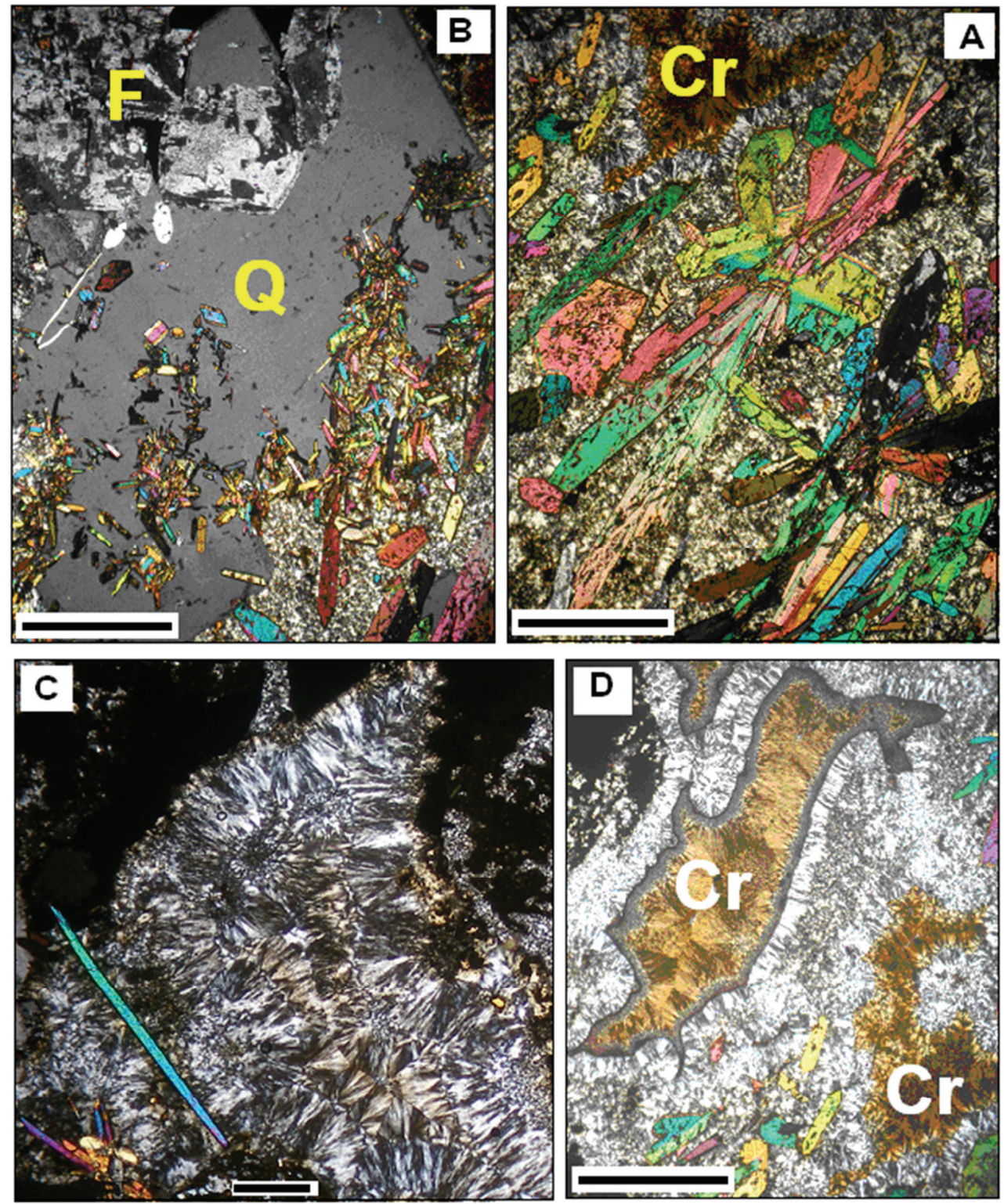

Fig. 2. (A) Cryptocrystalline (Cr) quartz and aegirine prisms in a groundmass of fine-grained quartz. (B) Cracked/interlocked feldspar altered to kaolinite plus opal (F), large platy quartz (Q) and aegirine prisms. (C) Spherulities of cryptocrystalline quartz plus a few aegirine needles. (D). Aegirine prisms, and fissures filled with cryptocrystalline quartz $(\mathrm{Cr})$ in fine-grained quartz. Scale bar $=60$ millimeters

Aegirine-augite is a clinopyroxene that has monoclinic symmetry and crystallizes in the space group C2/c. Its chemical formula can be written as $\{\mathrm{M} 2\}$ [M1] (T2) $\mathrm{O}_{6}$. The fiveto eight-coordinated $\mathrm{M} 2$ site can be occupied by $\mathrm{Na}, \mathrm{Ca}$, and others, and the six-coordinated M1 sites by $\mathrm{Fe}^{3+}, \mathrm{Fe}^{2+}, \mathrm{Al}$ and others. The four-coordinated $\mathrm{T}$ sites are preferentially 
occupied by $\mathrm{Si}, \mathrm{Ti}$ and others. The crystal chemistry of aegirine is related to the conditions of its formation. For example, M-O distances and polyhedral volumes of both the M1 and M2 sites in synthetic aegirines increase with increasing temperature (Cameron et al. 1973; Secco et al. 2007), but they are significantly decreased under higher pressure conditions (Secco et al. 2007; McCarthy et al. 2008). Therefore, one may use the chemical-structure parameters of natural aegirines to assess the geodynamic conditions under which the rocks evolved.

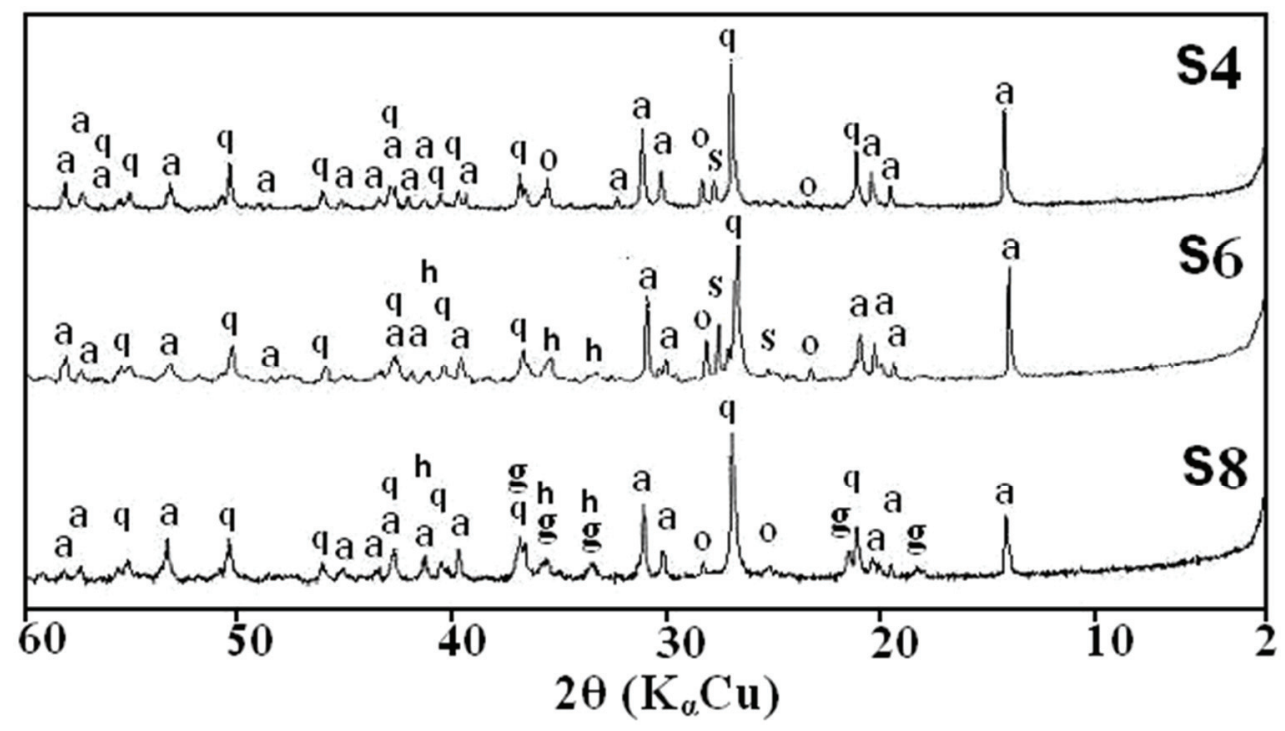

Fig. 3. XRD patterns of samples S4, S6 and S8. Identified peaks are: a (aegirine-augite), q (quartz), o (orthoclase), s (sanidine), h (hematite) and g (goethite)

The mineral percentages provided by x-ray diffraction are given in Table 1. Quartz averages $63.1 \%$, aegirine-augite, $27.0 \%$, sanidine, $6.4 \%$ and orthoclase, $3.5 \%$. These results are highly reproducible and very close to the chemical composition of the samples, suggesting a high level of consistency, and confidence in the results obtained from using the technique. X-ray diffraction has been used to semi-quantitatively determine the weight percent of constituents (e.g. Biscaye 1965; Poppe et al. 2001). The accuracy of the method increases when replicate analyses are performed and the results are averaged, and when the peak areas are not too small.

Chemical analyses expressed as oxide weight percentages are given in Table 2, along with other oxide data from Hassan (2005). The $\mathrm{SiO}_{2}$ contents range from 64.29-74.7\%, $\mathrm{Fe}_{2} \mathrm{O}_{3}$ from $12.3-22.4 \%$ and $\mathrm{FeO}, 0.06-0.77 \%$. These samples have low $\mathrm{K}_{2} \mathrm{O}$ contents $(0.2-$ $1.56 \%$ ), probably due to the alteration of $\mathrm{K}$-feldspar.

Molar ratios of $\left(\mathrm{K}_{2} \mathrm{O}+\mathrm{Na}_{2} \mathrm{O}\right) / \mathrm{Al}_{2} \mathrm{O}_{3}$ for the magmatic veins and their host granite exceed unity, with higher values in the veins. The rocks are peralkaline. In such magmas, the aluminum content is insufficient to accommodate all the alkalis in feldspars and micas (Mc Birney 1984). The excess alkalis are accommodated in other minerals, such as sodium iron $\left(\mathrm{Fe}^{3+}\right)$ silicate (aegirine) and sodium iron $\left(\mathrm{Fe}^{3+}, \mathrm{Fe}^{2+}\right)$ hydroxide silicates (riebeckite 
and arfvedsonite). Aegirine-augite is the alkaline phase in the veins. The aegirine content (as normative acmite) is higher (up to 6 times more) in the magmatic veins than in the host granite (Hassan 2005). Higher aegirine contents are associated with higher quartz contents and vice versa.

TABLE 1

Quantitative phase analysis results based on XRD peak intensity areas

\begin{tabular}{ccccc}
\hline Sample & $\begin{array}{c}\text { Quartz } \\
{[\%]}\end{array}$ & $\begin{array}{c}\text { Aegirine-augite } \\
{[\%]}\end{array}$ & $\begin{array}{c}\text { Sanidine } \\
{[\%]}\end{array}$ & $\begin{array}{c}\text { Orthoclase } \\
{[\%]}\end{array}$ \\
\hline S1 & 55.07 & 32.37 & 7.95 & 4.29 \\
S3 & 62.52 & 20.89 & 12.61 & 3.97 \\
S4 & 66.49 & 28.44 & 2.21 & 2.86 \\
S5 & 49.51 & 34.13 & 11.21 & 5.16 \\
S6 & 62.39 & 30.8 & 4.28 & 2.53 \\
S8 & 82.44 & 15.18 & 0 & 2.39 \\
Average & 63.07 & 26.97 & 6.38 & 3.53 \\
\hline
\end{tabular}

Measured precision for quartz $= \pm 0.13 \%$, aegirine-augite $= \pm 0.22 \%$, sanidine $= \pm 0.48 \%$ and orthoclase $= \pm 0.35 \%$.

TABLE 2

Chemical analyses for the vein samples and the host granite

\begin{tabular}{|c|c|c|c|c|c|c|c|c|c|c|c|}
\hline \multirow[t]{2}{*}{ Sample } & \multicolumn{9}{|c|}{ Radioactive Veins } & \multicolumn{2}{|c|}{$\begin{array}{c}\text { El-Seboah } \\
\text { Granite }\end{array}$} \\
\hline & S1 & S2 & S3 & S4 & S5 & S6 & S7 & S8 & S9 & G1 & G2 \\
\hline$(w t \%)$ & & & & & & & & & & & \\
\hline $\mathrm{SiO}_{2}$ & - & - & 74.7 & 73.6 & - & 67.96 & - & 64.29 & - & 70.0 & 68.1 \\
\hline $\mathrm{TiO}_{2}$ & - & - & 0.37 & 0.24 & - & - & - & - & - & 0.29 & 0.29 \\
\hline $\mathrm{Al}_{2} \mathrm{O}_{3}$ & - & - & 1.71 & 1.96 & - & 1.60 & - & 0.72 & - & 4.30 & 8.76 \\
\hline $\mathrm{Fe}_{2} \mathrm{O}_{3}$ & 14.3 & 19.1 & 13.5 & 12.3 & 15.8 & 18.8 & 19.3 & 22.4 & 20.2 & 7.00 & 8.93 \\
\hline $\mathrm{FeO}$ & 0.28 & 0.58 & 0.63 & 0.28 & 0.77 & 0.56 & 0.06 & 0.58 & 0.42 & 1.60 & 1.44 \\
\hline $\mathrm{CaO}$ & - & - & 0.86 & 1.86 & - & 0.63 & - & 0.56 & - & 2.10 & 1.29 \\
\hline $\mathrm{MgO}$ & - & - & 1.53 & 2.06 & - & 0.04 & - & 0.08 & - & 4.10 & 1.27 \\
\hline $\mathrm{Na}_{2} \mathrm{O}$ & - & - & 2.97 & 4.71 & - & 2.37 & - & 2.17 & - & 4.82 & 3.97 \\
\hline $\mathrm{K}_{2} \mathrm{O}$ & - & - & 1.14 & 1.56 & - & 1.16 & - & 0.20 & - & 3.67 & 4.16 \\
\hline $\begin{array}{l}\text { Peralkalinity } \\
\text { Index }\end{array}$ & & & 3.58 & 4.82 & & 3.22 & & 5.23 & & 2.77 & 1.26 \\
\hline
\end{tabular}

Measured precision as determined from two duplicates was $\pm 0.51 \%$ for $\mathrm{FeO}$ and \pm 1.03 for $\mathrm{Fe}_{2} \mathrm{O}_{3}$. Dash: not analyzed. ${ }^{\mathrm{a}}$ Peralkalinity index $=$ mole $\left(\mathrm{K}_{2} \mathrm{O}+\mathrm{Na}_{2} \mathrm{O} / \mathrm{Al}_{2} \mathrm{O}_{3}\right)$.

Mössbauer spectra of all samples analyzed include the asymmetric $\mathrm{Fe}^{3+}$ of aegirineaugite \pm a sextet of $\mathrm{Fe}^{3+}$ due to hematite \pm another $\mathrm{Fe}^{3+}$ sextet due to goethite. Representative spectra are shown in Fig. 4. According to De Grave et al. (1998), the 
asymmetric feature is due to relaxation effects and persists up to $480 \mathrm{~K}$, and most likely higher. As in Table 3, the aegirine-augite $\mathrm{Fe}^{3+}$, with relative spectral areas or RA values of 37.3 to $100 \%$, has quadrupole splitting $\left(\Delta \mathrm{E}_{\mathrm{Q}}\right)$ of $\sim 0.30 \mathrm{~mm} / \mathrm{s}$ and an isomer shift $(\delta)$ of $\sim 40 \mathrm{~mm} / \mathrm{s}$ that are typical of $\mathrm{Fe}^{3+}$ in octahedral coordination $(\mathrm{M} 1)$ sites. The $\Delta \mathrm{E}_{\mathrm{Q}} \mathrm{mm} / \mathrm{s}$ deviates slightly from the diagnostic value $(0.29 \mathrm{~mm} / \mathrm{s})$ reported for well-ordered aegirine where iron exists only as ferric ion (Dollase, Gustafson 1982). This suggests that the samples investigated are largely the aegirine $\left(\mathrm{NaFe}^{3+} \mathrm{Si}_{2} \mathrm{O}_{6}\right)$ molecule with well-ordered iron sites and in agreement with EDX analysis suggesting the presence of only small amounts of augite impurities $(\sim 2.5 \%)$. In natural systems, aegirine forms solid solutions with augite $\left.(\mathrm{Ca}, \mathrm{Mg}, \mathrm{Fe}) \mathrm{SiO}_{3}\right)$, hedenbergite $\left(\mathrm{CaFeSi}_{2} \mathrm{O}_{6}\right)$ and diopside $\left(\mathrm{CaMgSi}_{2} \mathrm{O}_{6}\right)$, where the $\mathrm{Na}^{+}$is partially replaced by $\mathrm{Ca}^{2+}$ with $\mathrm{Fe}^{2+}$ and $\mathrm{Mg}^{2+}$ replacing $\mathrm{Fe}^{3+}$ for charge balance. This causes a localized distortion of the electron cloud at the $\mathrm{Fe}^{3+}$ site throughout the series, thereby increasing the $\Delta \mathrm{E}_{\mathrm{Q}}$ value, e.g. from $0.29 \mathrm{~mm} / \mathrm{s}$ for the Na-end member to $0.46 \mathrm{~mm} / \mathrm{s}$ for the $20 \mathrm{Na}-80 \mathrm{Ca}$ composition (De Grave et al. 1998).

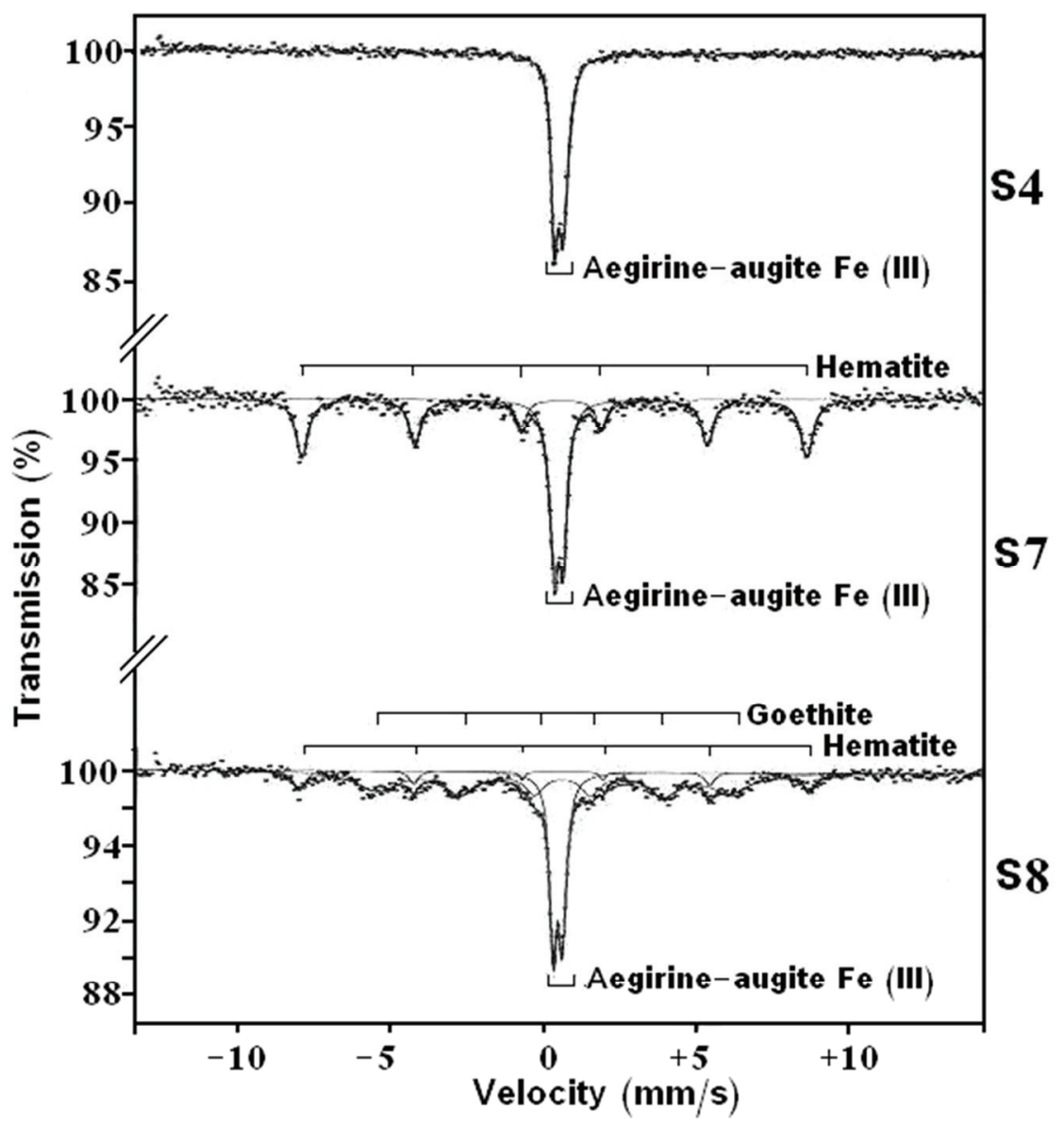

Fig. 4. Mössbauer spectra of samples S4, S7 and S8, giving a representative picture of the differences found by Mössbauer analysis for the radioactive veins studied 
The hematite and goethite sextets each have a distinctive hyperfine magnetic field $(\mathrm{H})$ of $\sim 51.7$ and $\sim 35.5$ tesla $(\mathrm{T}$ ), respectively (Table 3 ). These values indicate pure oxide phases (Kuzmann et al. 2003). This is consistent with the vein samples containing only minor amounts of $\mathrm{Al}\left(<2 \mathrm{wt} \% \mathrm{Al}_{2} \mathrm{O}_{3}\right)$ and $\mathrm{Ti}\left(<0.4 \mathrm{wt} \% \mathrm{TiO}_{2}\right)$ which, otherwise, because $\mathrm{Al}^{3+}$ (Hassan 2008) and $\mathrm{Ti}^{4+}$ (Dyar et al. 2004) are diamagnetic, would substitute into some iron positions, depressing the hyperfine field. A noteworthy feature in Table 3 is that the goethite sextet exhibits a considerable line broadening, with line width $(\Gamma)$ values from $1.51-1.59 \mathrm{~mm} / \mathrm{s}$. Although it proved impossible to resolve closely overlapping peaks, their breadth is indicative of $\mathrm{Fe}$ ions being located in more than one site in the mineral structure. Line broadening in room-temperature Mössbauer spectra of goethite has been attributed to poor mineral crystallinity (Murad 1982). Generally, goethite (and other iron-oxide phases)

TABLE 3

Mössbauer hyperfine parameters of the samples measured at room temperature

\begin{tabular}{|c|c|c|c|c|c|c|}
\hline Sample & $\begin{array}{c}\mathrm{H} \\
{[\mathrm{T}]}\end{array}$ & $\begin{array}{c}\Delta \mathrm{E}_{\mathrm{Q}} \\
{[\mathrm{mm} / \mathrm{s}]}\end{array}$ & $\begin{array}{c}\delta \\
{[\mathrm{mm} / \mathrm{s}]}\end{array}$ & $\begin{array}{c}\Gamma \\
{[\mathrm{mm} / \mathrm{s}]}\end{array}$ & $\begin{array}{l}\text { RA } \\
{[\%]}\end{array}$ & Assessment \\
\hline S1 & - & 0.30 & 0.40 & 0.32 & 100 & aegirine-augite- $\mathrm{Fe}^{3+}$ \\
\hline $\mathrm{S} 2$ & - & 0.30 & 0.40 & 0.33 & 100 & aegirine-augite- $\mathrm{Fe}^{3+}$ \\
\hline S3 & - & 0.30 & 0.40 & 0.34 & 100 & aegirine-augite- $\mathrm{Fe}^{3+}$ \\
\hline S4 & - & 0.30 & 0.40 & 0.35 & 100 & aegirine-augite- $\mathrm{Fe}^{3+}$ \\
\hline \multicolumn{7}{|r|}{ 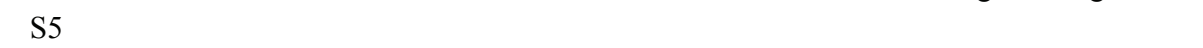 } \\
\hline & - & 0.30 & 0.37 & 0.30 & 55.6 & aegirine-augite- $\mathrm{Fe}^{3+}$ \\
\hline & 51.08 & -0.25 & 0.35 & 0.35 & 44.4 & hematite- $\mathrm{Fe}^{3+}$ sextet \\
\hline \multicolumn{7}{|r|}{ 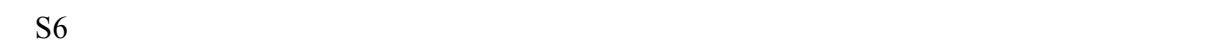 } \\
\hline & - & 0.31 & 0.38 & 0.34 & 41.2 & aegirine-augite- $\mathrm{Fe}^{3+}$ \\
\hline & 51.8 & -0.22 & 0.38 & 0.50 & 58.8 & hematite- $\mathrm{Fe}^{3+}$ sextet \\
\hline \multicolumn{7}{|r|}{ 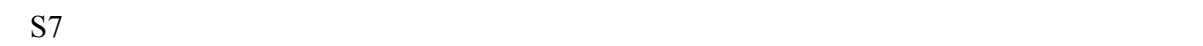 } \\
\hline & - & 0.30 & 0.38 & 0.35 & 44.3 & aegirine-augite- $\mathrm{Fe}^{3+}$ \\
\hline & 51.7 & -0.22 & 0.33 & 0.48 & 55.7 & hematite- $\mathrm{Fe}^{3+}$ sextet \\
\hline \multicolumn{7}{|l|}{ S8 } \\
\hline & - & 0.30 & 0.40 & 0.29 & 34.8 & aegirine-augite- $\mathrm{Fe}^{3+}$ \\
\hline & 51.7 & -0.24 & 0.38 & 0.47 & 6.80 & hematite- $\mathrm{Fe}^{3+}$ sextet \\
\hline & 35.6 & -0.17 & 0.45 & 1.59 & 58.8 & goethite- $\mathrm{Fe}^{3+}$ sextet \\
\hline \multicolumn{7}{|l|}{ S9 } \\
\hline & - & 0.30 & 0.40 & 0.29 & 37.3 & aegirine-augite- $\mathrm{Fe}^{3+}$ \\
\hline & 51.6 & -0.21 & 0.38 & 0.42 & 15.9 & hematite-Fe $\mathrm{Fe}^{3+}$ \\
\hline & 35.5 & -0.17 & 0.45 & 1.51 & 46.8 & goethite- $\mathrm{Fe}^{3+}$ \\
\hline \multicolumn{7}{|l|}{$\mathrm{G} 2$} \\
\hline & - & 0.29 & 0.40 & 0.33 & 71.9 & aegirine-augite- $\mathrm{Fe}^{3+}$ \\
\hline & - & 2.05 & 1.07 & 0.89 & 8.70 & aegirine-augite- $\mathrm{Fe}^{2+}$ \\
\hline & 50.9 & -0.20 & 0.38 & 0.56 & 19.4 & hematite- $\mathrm{Fe}^{3+}$ \\
\hline
\end{tabular}

Note: $\delta$ is calibrated against metallic Fe. Measured precision is $\pm 0.6 \mathrm{~T}$ for $\mathrm{H}$ and $\pm 0.04 \mathrm{~mm} / \mathrm{s}$ for $\Delta \mathrm{E}_{\mathrm{Q}}$. For $\delta$ and $\Gamma$, the precision was roughly $\pm 0.04 \mathrm{~mm} / \mathrm{s}$, and for $\mathrm{RA} \pm 2.73-6.85 \%$. 
forms under conditions of high oxidation and/or radioactivity (particularly $\alpha$-radiation), such those of the present study, and generally do not exhibit long-range order. Such materials are difficult to study by XRD, but are easily identified by Mössbauer spectroscopy on the basis of their magnetic properties.

TABLE 4

Comparison of percent oxidation of iron as determined by chemical and Mössbauer methods

\begin{tabular}{cccc}
\hline \multirow{2}{*}{ Sample } & $\% \Sigma \mathrm{Fe}$ & \multicolumn{2}{c}{$\%\left(\mathrm{Fe}^{3+} / \Sigma \mathrm{Fe}\right)$} \\
\cline { 3 - 4 } & & Chemical & Mössbauer \\
\hline S1 & 14.60 & 98.08 & 100 \\
S2 & 19.72 & 98.38 & 100 \\
S3 & 14.14 & 95.54 & 100 \\
S4 & 12.62 & 97.78 & 100 \\
S5 & 16.60 & 95.36 & 100 \\
S6 & 19.35 & 97.11 & 100 \\
S7 & 19.31 & 99.69 & 100 \\
S8 & 22.97 & 97.48 & 100 \\
S9 & 20.65 & 97.92 & 100 \\
G1 & 8.60 & 81.90 & - \\
G2 & 10.37 & 86.11 & $91.3 *$ \\
\hline
\end{tabular}

Dash: not analyzed; ${ }^{*}$ analysis from Hassan (2009b).

In Table 4, a comparison is made between percent oxidation of iron $\left(\mathrm{Fe}^{3+} / \Sigma \mathrm{Fe}\right)$ determined by relative intensities (Mössbauer method) and chemical analysis. Throughout the range of total-iron content, the two methods yield slightly different $\mathrm{Fe}^{3+} / \Sigma \mathrm{Fe}$ values: (100\% for Mössbauer; $95.36-99.69 \%$ for the chemical method). There is either an error in the chemical procedure used (which might be caused by the difficulty of working with these low $\mathrm{Fe}^{2+}$ samples) or the Mössbauer measurement is deceptive. The experimental error in the chemical analyses is not large enough to explain the observed difference. However, it should be noted that, especially in aegirine, compounds with low $\mathrm{Fe}^{2+}$ concentrations exhibit very broad Mössbauer lines due to next nearest neighbour effects (Hassan 2009a, b) and that such contribution can be overlooked or, in the present study, may be screened by the hematite contributions. This situation can be improved by using a Mössbauer source with very high $\gamma$-ray flux (e.g. $100 \mathrm{mCi}$ sources) and/or by cooling the sample with liquid helium or nitrogen. However, such procedures were not available for this study. Thus, some disparity between the Mössbauer and wet chemistry was probably inevitable.

In iron-bearing minerals, the ratio $\mathrm{Fe}^{3+} / \Sigma \mathrm{Fe}$ is a function of crystal structure and the $f_{\mathrm{O}_{2}}$ at crystallization (McCanta et al. 2003). Olivine, for example, does not allow significant $\mathrm{Fe}^{3+}$ into its structure and may not record changes in magmatic $f_{\mathrm{O}_{2}}$. However, the chemistry 
of iron in clinopyroxene tends to be steady and, thus, makes it a potential oxybarometer (McCanta et al. 2004). The stability of clinopyroxene (mainly aegirine phases) has been reported in peralkaline complexes (Marks et al. 2003). Therefore, it seems that the vein samples, with the Fe-carriers being aegirine-augite plus some hematite and goethite, are likely to be primary and their elevated $\mathrm{Fe}^{3+} / \Sigma \mathrm{Fe}$ values to reflect formation under high $f_{\mathrm{O}_{2}}$ conditions. Such conditions are compatible with the veins being extreme differentiates of peralkaline magmas and are also consistent with them having high levels of other redoxsensitive elements, such as $\mathrm{Nd}, \mathrm{Ce}, \mathrm{Zr}, \mathrm{Y}, \mathrm{Nb}, \mathrm{Sm}$, Th and $\mathrm{U}$.

\section{Conclusions}

This study has been focused on the structure composition of $\mathrm{Fe}$ in radioactive veins from the El-Seboah granite. The Fe constitutes $12.3-22.4 \%$ by weight of the sample. It occurs as aegirine-augite and, to a lesser extent, hematite and goethite. These minerals as shown by Mössbauer spectroscopy are pure and have ordered sites for Fe. The Fe exists mainly as $\mathrm{Fe}^{3+}$ ions, suggesting formation under conditions of high oxygen fugacity.

Acknowledgements. The author acknowledges the staff of the "Toshki Uranium Study and Evaluation Project" for field assistance, Dr. E.M. Abuzeid for taking the photomicrographs, Professor I. Kashif and Professor S.S. Ata-Allah for Mössbauer analyses. Thanks are due to the reviewers who aided in improving the manuscript.

\section{References}

Abdel Monem, H.M., \& El-Afandy, A.H. (1997). Geochemistry of beneficiation studies of U-Th bearing minerals of Um Risha ring complex, Eastern Desert, Egypt. Egyptian Mineralogist, 9, 43-58.

Biscaye, P.E. (1965). Mineralogy and sedimentation of recent deep-sea clays in the Atlantic Ocean and adjacent seas and oceans. Geological Society of America Bulletin, 76, 803-832.

Cameron, M., Sueno, S., Prewitt, C.T., \& Papike, J.J. (1973). High-temperature crystal chemistry of Acmite, diopside, hedenbergite, jadeite, spodumene, and ureyite. American Mineralogist, 58, 594-618.

De Grave, E., Van Alboom, A., \& Eeckhout, S.G. (1998). Electronic and magnetic properties of a natural aegirine as observed from its Mössbauer spectra. Physics and Chemistry of Minerals, 25, 378-388.

Dollase, W.A., \& Gustafson, W.I. (1982). Mössbauer spectral analysis of the sodic clinopyroxenes. American Mineralogist, 67, 311-327.

Dyar, M.D., McEnroe, S.A., Murad, E., Brown, L.L., \& Schiellerup, H. (2004). The relationship between exsolution and magnetic properties in hemo-ilmenite: Insights from Mössbauer spectroscopy with implications for planetary magnetic anomalies. Geophysical Research Letters, 31, L04608. DOI: 10.1029/2003GL019076.

Hassan, K.M. (2005). Geochemical assessment of radioactive lava pockets in El-Seboah granite, Toshki area, south Western Desert, Egypt. Annals of the Geological Survey of Egypt, 28, 195-204.

Hassan, K.M. (2008). Characterization of granitic soil samples from Egypt by ${ }^{57} \mathrm{Fe}$ Mössbauer spectroscopy. Isotope and Radiation Research, 40, 107-116.

Hassan, K.M. (2009a). Rhyolite-dacite-trachyandesite association: a Mössbauer spectroscopy study. Hyperfine Interactions, 192, 101-107.

Hassan, K.M. (2009b). Characterization of granites by ${ }^{57} \mathrm{Fe}$ Mössbauer spectroscopy. Mineralogia, 40(1-4), 95106.

Khalaf, I.M., Abdel Monem, A.A., Attawiya, Y.M., Ammar, S.E., \& El-Sawey, E.H. (2000). Petrology, geochemistry and radioactivity of Abu Aqarib Alkali granite, Central-Eastern Desert, Egypt. Annals of the Geological Survey of Egypt, 38, 261-274. 
Kuzmann, E., Nagy, S., \& Vértes, A. (2003). Critical review of analytical applications of Mössbauer spectroscopy illustrated by mineralogical and geological examples. Pure Applied Chemistry, 75, 801-858.

List, F.K., El-Gaby, S., \& Tehrani, R. (1989). The basement rocks in the Eastern and Western Deserts and Sinai. In M. Hermina, E., Klitzsch \& S. List (Eds.), Stratigraphic lexicon and explanatory note to the geologic map of Egypt 1:500000 (pp. 33-56). Cairo, Egypt: Egyptian General Petroleum Corporation.

Marks, M., Vennemann, T., Siebel, W., \& Markl, G. (2003). Quantification of magmatic and hydrothermal processes in a peralkaline syenite-alkali granite complex based on textures, phase equilibria, and stable and radiogenic isotopes. Journal of Petrology, 44, 1247-1280.

Mc Birney, A.R. (1984). Igneous petrology. California: Freeman Cooper \& Company.

McCanta, C., Rutherford, M.D., Dyar, M.D., \& Delaney, J.S. (2003). $\mathrm{Fe}^{3+} / \sum \mathrm{Fe}$ ratios in pigeonite as a function of $f_{\mathrm{O}_{2}}$ : a preliminary investigation. Proceedings - 34th Lunar and Planetary Science Conference, 17-21 March 2003 (Abstract 1361). Lunar and Planetary Institute. League City, Texas, U.S.A.

McCanta, C., Rutherford, M.D., Dyar, M.D., \& Delaney, J.S. (2004). The relationship between clinopyroxene Fe ${ }^{3+}$ content and oxygen fugacity. Proceedings - 35th Lunar and Planetary Science Conference, 15-19 March 2004 (Abstract 1198). Lunar and Planetary Institute. Houston, Texas, U.S.A.

McCarthy, A.C., Downs, R.T., Thompson, R.M., \& Redhammer, G.J. (2008). In situ high-pressure single-crystal $\mathrm{X}$-ray study of aegirine, $\mathrm{NaFe}^{3+} \mathrm{Si}_{2} \mathrm{O}_{6}$, and the role of $\mathrm{M} 1$ size in clinopyroxene compressibility. American Mineralogist, 93, 1829-1837.

Murad, E. (1982). The characterization of goethite by Mössbauer spectroscopy. American Mineralogist, 67, $1007-$ 1011.

NMA (2000). Toshki project phase I. Maadi, Kattamyia, Cairo, Egypt: Nuclear Materials Authority.

Poppe, L.J., Paskevich, V.F., Hathaway, J.C., \& Blackwood, D.S. (2001). U. S. Geological Survey Open-File Report 01-041 (A laboratory manual for x-ray powder diffraction) from http://pubs.usgs.gov/of/2001/of01041/index.htm.

Scott, W.W. (1958). Standard Methods of Chemical Analysis. New Jersey: D. Van Nostrand Company Inc.

Scott, W.W., \& Furman, N.H. (1952). Standard methods of chemical analysis (5 ed.). New York: Van Nostrand Company Inc.

Secco, L., Guastoni, A., Nestola, F., Rehammer, G.J., \& Negro, A.D. (2007). Crystal chemistry of aegirine as an indicator of P-T conditions. American Mineralogist, 71, 249-255.

Welcher, F.J. (1958). The analytical uses of ethylenediaminetetraacetic acid. New Jersey: D. Van Nostrand Company Inc. 
